\title{
Anesthetists and surgeons in ensuring preoperative optimization
}

\section{Preoperatif anestezistler ve cerrahlar \\ optimizasyonun}

sağlanmasında

\section{Sevgi Kesici ${ }^{1}$, Ulku Aygen Türrkmen²}

Department of Anesthesiology and Reanimation, Hamidiye Etfal Training and Research Hospital, University of Health Sciences, Istanbul, Turkey ${ }^{2}$ Department of Anesthesiology and Reanimation, Gaziosmanpaşa Taksim Training and Research Hospital, University of Health Sciences, Istanbul, Turkey

Corresponding author: Sevgi Kesici, MD, Department of Anesthesiology and Reanimation, Hamidiye Etfal Training and Research Hospital, University of Health Sciences, Istanbul, Turkey

E-mail: md.kesici@mynet.com

Received/Accepted: July 01, 2019/September 25, 2019

Conflict of interest: There is not a conflict of interest.

\section{SUMMARY}

Objective: This survey study was designed with the aim of questioning tobacco and alcohol use as two major components of preoperative optimization, evaluating the elements of the preoperative period other than the treatment of anemia, evaluating whether these elements were performed in compliance with the protocols by anesthetists and surgeons, and suggesting solutions for overcoming deficiencies.

Method: Specialist physicians in anesthesia and surgeons from several branches, who worked in 4 different healthcare centers in Istanbul, were included in this 15-question survey.

Results: A total of 116 physicians participated in this survey study. Of the participating physicians, $47(40.5 \%)$ were anesthetists, and $69(59.5 \%)$ were surgeons. A total of $115(99.1 \%)$ physicians answered "yes" to the following question: "Do you inform and train your patient in the preoperative period about the scheduled surgical procedure/anesthesia method and the essential principles?". To the question "do you stress to your patients in the preoperative period that stopping smoking is necessary for the period of 4 weeks prior to surgery?", 88 (75.9\%) physicians answered "yes." Only $47(40.5 \%)$ physicians answered "yes" to the following question: "In the preoperative period, do you stress to your patients using alcohol that stopping alcohol use is necessary for the period of 4 weeks prior to surgery?"

Conclusions: Our survey study conducted with the participation of physicians with an experience of more than 10 years demonstrated favorable outcomes, revealing that all physicians provided information and training for their patients in the preoperative period and all but 1 physician followed up the blood sugar level of diabetic patients for regulating the blood sugar levels. However; we are of the opinion that further collaboration of physicians within a team concept and in compliance with the preoperative optimization guidelines will be useful to ensure early and fast recovery in the postoperative period by limiting the tobacco/alcohol use of patients in the preoperative period, providing appropriate nutrition preoperatively, enabling access of patients to prehabilitation, administering adequate premedication, and providing anemia management.

Keywords: Preoperative optimization, ERAS, anesthetist, surgeon
Sevgi Kesici

Ulku Aygen Türkmen

ORCID IDs of the authors: S.K. 0000-0002-8276-6039 U.A.T. 0000-0002-7280-6420 


\section{ÖZET}

Amaç: Preoperatif optimizasyonun ana bileşenlerinden olan, sigara-alkol kullanımının sorgulanması, aneminin tedavisi dışında ERAS'ın diğer preoperatif dönem bileşenlerinin değerlendirilmesi ve hem anestezi doktoru hem de cerrah tarafından klavuzlara uygun şekilde uygulanıp uygulanmadığının değerlendirilmesi ve ayrıca eksikler konusunda çözüm önerilerinin oluşturulması amacıyla bu anket çalışması planlanmıştır.

Materyal ve Metod: Etik kurul onayı alındıktan sonra, 15 soru içeren bu anket çalışmasına İstanbul'da 4 sağlık merkezinde görev alan anestezi uzmanları ve diğer cerrahi branşlardaki uzman hekimler dahil edildi.

Bulgular: Bu anket çalışmamıza toplam 116 hekim katıldı. Katılan hekimlerin 47'si (\% 40,5) anestezist, 69'u (\% 59,5) cerrah idi. ' 'Hastanıza yapması gerekenleri, yapılacak olan cerrahi işlemi/anestezi yöntemi ve cerrahi işlemi/anestezinin gerektirdiği prensipler ile ilgili ameliyat öncesi bilgilendirme ve eğitim veriyor musunuz?'” sorusuna; hekimlerin 115'i $(\% 99,1)$ tarafindan Evet cevabı verildi. "Sigara kullanan hastalara preoperatif dönemde en az 4 hafta önce sigaray1 bırakması gerektiğini vurguluyor musunuz?' sorusuna; hekimlerin 88'i $(\% 75,9)$ tarafindan Evet cevabi verildi. ' Alkol kullanan hastalara preoperatif dönemde en az 4 hafta önce alkolü bırakması gerektiğini vurguluyor musunuz?' sorusuna; hekimlerin sadece 47 `si $(\% 40,5)$ tarafindan Evet cevabı verildi.

Sonuç: Çoğunlukla 10 yılın üzerinde uzmanlık deneyimi olan hekimlerin katılımı ile gerçekleştirilen anket çalışmamızın değerlendirmesinde; hastalara preoperatif bilgilendirme ve eğitim verilmeleri ile diyabetik hastaların kan şekeri regülasyonunun takipleri açısından 1'er hekim dışında tüm hekimlerin bu işlemleri uygulaması yüz güldürücü sonuçlarımızdandır. Ancak hastaların postoperatif erken ve hızlı derlenmesini sağlamak için preoperatif sigara/alkol kısıtlaması, preoperatif nutrisyon, prehabilitasyon, premedikasyon ve preoperatif anemi yönetimi açısından hekimlerin preoperatif optimizasyon klavuzlarına uygun olarak ekip anlayışı ile çalışmasının faydalı olacağı kanaatindeyiz.

Anahtar sözcükler: Preoperatif optimizasyon, ERAS, anestezist, cerrah

\section{INTRODUCTION}

"Enhanced Recovery After Surgery" (ERAS) is a set of evidence-based care pathways performed by a multidisciplinary professional healthcare team in order to assist patients in achieving a faster recovery in the postoperative period ${ }^{1}$. It has been proven that perioperative complication rates, morbidity, the length of hospital stay, and cost of hospitalization are reduced by the implementation of ERAS protocols ${ }^{2,3}$. ERAS protocol comprises multiple components, including preoperative optimization ${ }^{1}$.

This survey study was designed with the aim of questioning tobacco and alcohol use as two major components of preoperative optimization, evaluating the elements of the preoperative period other than the treatment of anemia, evaluating whether these elements were performed in compliance with the protocols by anesthetists and surgeons, and suggesting solutions for overcoming deficiencies.

\section{MATERIAL AND METHODS}

After obtaining the approval of the Ethics Committee, specialist physicians in anesthesia and surgeons from several branches, who worked in 4 different healthcare centers in Istanbul, were included in this 15-question survey. The survey questions have been presented in Figure 1. 
ANESTHETISTS AND SURGEONS IN

PREOPERATIVE OPTIMIZATION: QUESTIONNAIRE

Would you answer the below questions about the preoperative preparation of the elective surgery patients (adults)?

1. What is your specialty?

$\square$ Anesthetist $\square$ Surgeon (Specialty:.......)

2. What is your length of experience in your area of specialty?
$\square 0-5$ years
$\square 6-9$ years

$\square>10$ years

3. Do you inform and train your patient in the preoperative period about the scheduled surgical procedure/anesthesia method and the essential principles?

$\square$ Yes

$$
\square \text { No }
$$

4. Do you stress to your patients in the preoperative period that stopping smoking is necessary for the period of 4 weeks prior to surgery?

$\square$ Yes

$$
\square \text { No }
$$

5. If you have answered yes, can you give information on whether it is effective? $\square$ Yes, the patient undergoes surgery after stopping smoking

$\square$ No, the patient does not like to delay surgery

$\square$ No, the surgeon does not like to delay surgery even though the patient likes to undergo surgery after stopping smoking $\square$ Other

6. In the preoperative period, do you stress to your patients using alcohol that stopping alcohol use is necessary for the period of 4 weeks prior to surgery?

$\square$ Yes

$$
\square \text { No }
$$

7. If you have answered yes, can give information on whether it is effective? $\square$ Yes, the patient undergoes surgery after stopping alcohol use

$\square$ No, the patient does not like to delay surgery

$\square$ No, the surgeon does not like to delay surgery even though the patient likes to undergo surgery after stopping alcohol use $\square$ Other

8. Which of these describe your practice to ensure the fasting of the patient prior to surgery?

$\square$ Only the intake of fluids is allowed for 24 hours preoperatively and absolute fasting of the patient for 8 hours prior to surgery

$\square$ Stopping solid food intake 6 hours prior to surgery and stopping the intake of fluids 2 hours prior to surgery

$\square$ Other
9. Do you order carbohydrate loading for your patient, or do you perform it in your patient?

$$
\square \text { Yes } \quad \square \text { No }
$$

10. If you have answered yes, can give information about what is your preferred method for performing the carbohydrate loading test?

$\square$ Of a carbohydrate-rich solution, $800 \mathrm{~mL}$ is administered 8 hours before the surgery, and $400 \mathrm{~mL}$ is administered $2-3$ hours prior to surgery $\square$ Other

11. Do you refer your patients, who are older or who will undergo major surgery, to exercise program in the preoperative period?

$$
\square \text { Yes } \quad \square \text { No }
$$

12. Do you order/administer premedication to patients in the preoperative period?

$$
\square \text { Yes } \quad \square \text { No }
$$

13. To patients having an indication of prophylaxis therapy for thromboembolism, do you order/administer low-molecular-weight heparin prophylaxis in the night prior to the operation?
$\square$ Yes
$\square$ Sometimes
$\square$ No

14. Do you monitor the blood glucose levels of diabetic patients in the preoperative period?
$\square$ Yes
$\square$ No

15. For patients, who will undergo major surgery, what is the lower normal limit of hemoglobin you accept in your clinical practice to indicate that you start treatment for anemia and schedule the surgery accordingly? $\square$ Females $<12$; Males $<13 \quad \square$ Females $<10$; Males $<10 \quad \square$ Females $<7$; Males $<8$ $\square$ Other

Figure 1: The survey questions 
The universe of the study consisted of specialist physicians in anesthesia and surgeons from several branches, who worked in 4 different healthcare centers in Istanbul. The smallest size of the study sample, which would allow for performing statistical estimations, was calculated to be 116.4 in a universe count of 220 in a $95 \%$ confidence interval with a $\pm 5 \%$ sampling error. For the statistical analysis of the study data, SPSS 22.0 statistical package program was used. The results were evaluated in a $95 \%$ confidence interval at a plevel of $<0.05$ for significance.

\section{RESULTS}

A total of 116 physicians participated in this survey study. Of the participating physicians, 47 (40.5\%) were anesthetists, and $69(59.5 \%)$ were surgeons.

The physician distribution by the variable of the specialist experience duration revealed that 26 (22.4\%) physicians had an experience duration of $0-5$ years, 34 physicians (29.3\%) had an experience duration of 6-9 years, and $56(48.3 \%)$ physicians had an experience duration of $>10$ years.
A total of 115 (99.1\%) physicians answered "yes" to the following question: "Do you inform and train your patient in the preoperative period about the scheduled surgical procedure/anesthesia method and the essential principles?"

To the question "do you stress to your patients in the preoperative period that stopping smoking is necessary for the period of 4 weeks prior to surgery?", 88 (75.9\%) physicians answered "yes." The responses of the anesthetists and surgeons to the question "if you have answered yes, can give information on whether it is effective?" have been presented in Figure 2. Only 47 (40.5\%) physicians answered "yes" to the following question: "In the preoperative period, do you stress to your patients using alcohol that stopping alcohol use is necessary for the period of 4 weeks prior to surgery?" The responses of the anesthetists and surgeons to this question have been presented in Figure 3. The responses of the physicians and anesthetists to the following question "if you have answered yes, can give information on whether it is effective?" have been presented in Figure 4.

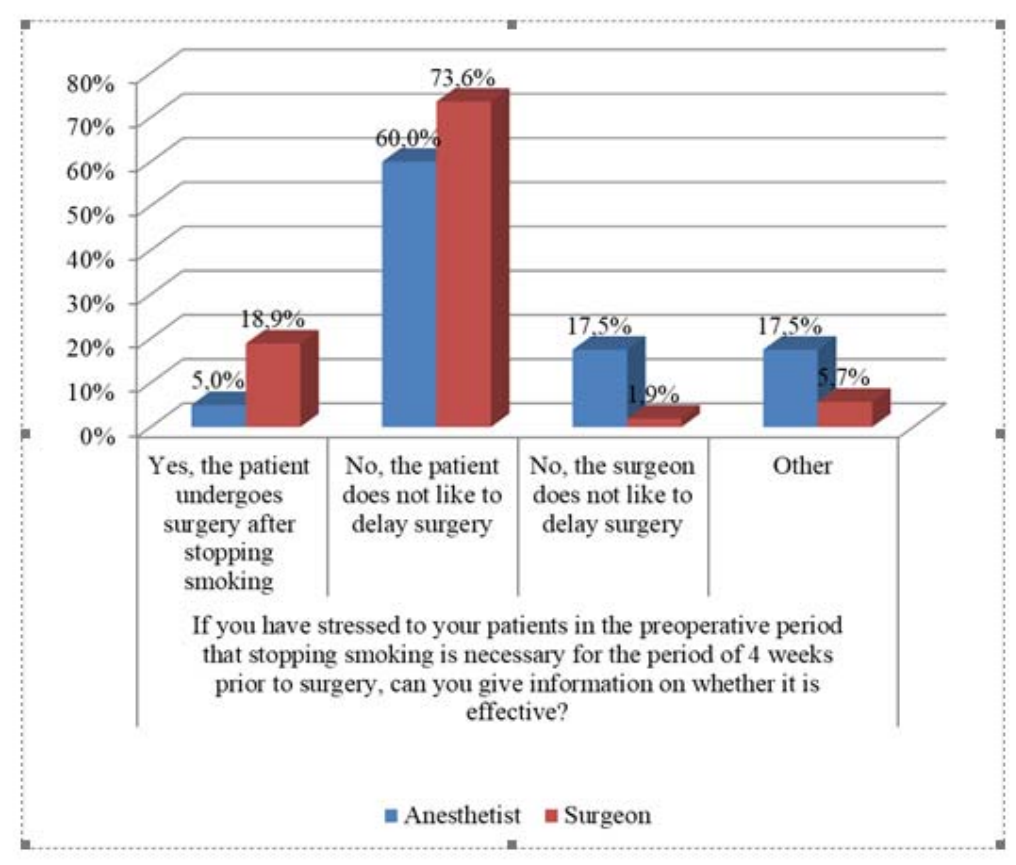

Figure 2: 'If you have stressed to your patients in the preoperative period that stopping smoking is necessary for the period of 4 weeks prior to surgery, can you give information on whether it is effective?" the answers of this question. 


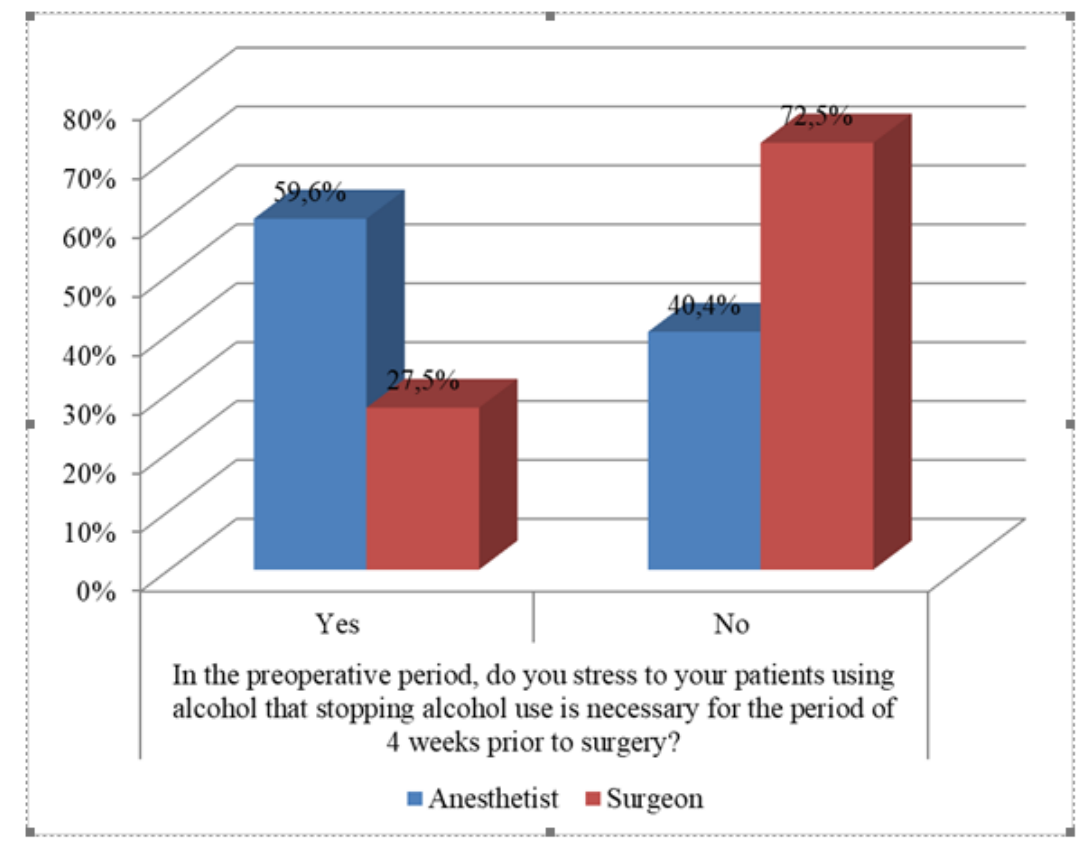

Figure 3: ' In the preoperative period, do you stress to your patients using alcohol that stopping alcohol use is necessary for the period of 4 weeks prior to surgery?" the answers of this question.

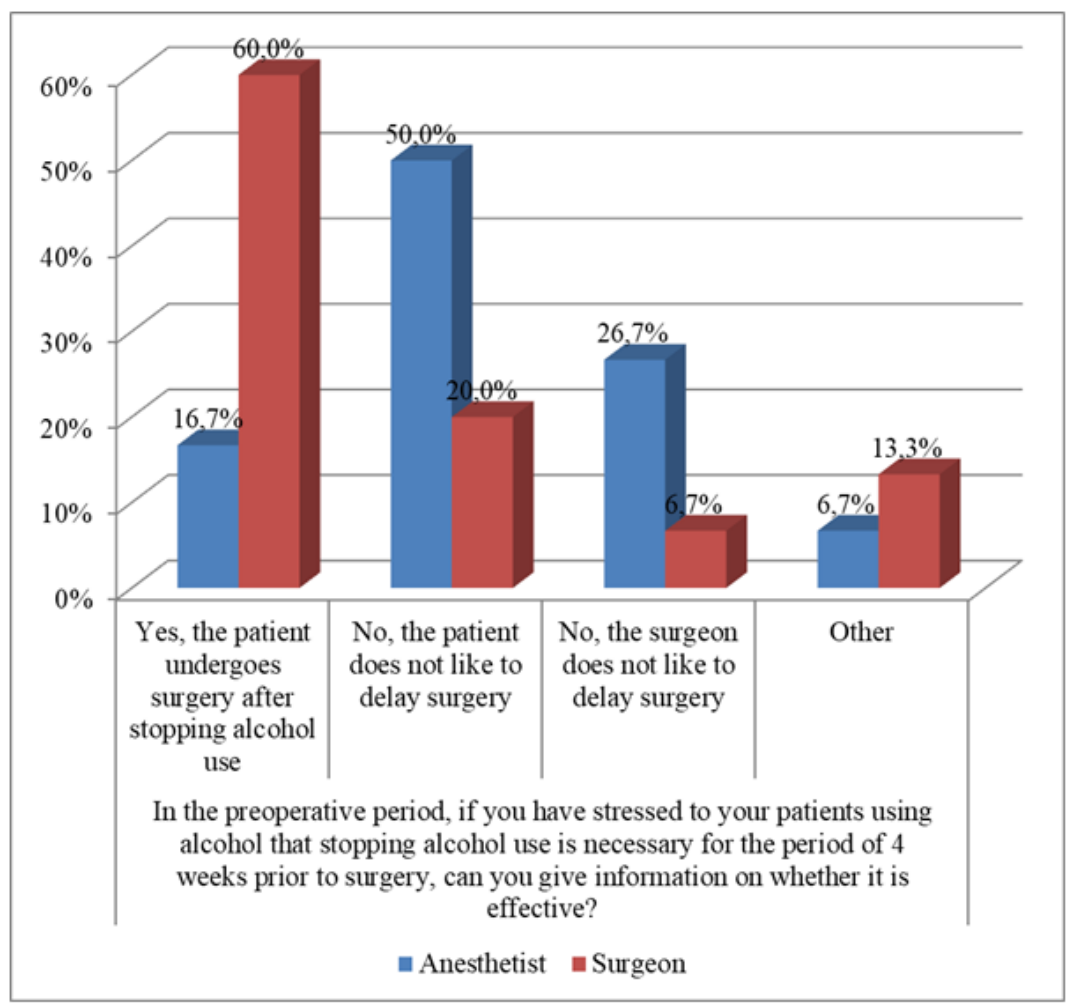

Figure 4: 'In the preoperative period, if you have stressed to your patients using alcohol that stopping alcohol use is necessary for the period of 4 weeks prior to surgery, can you give information on whether it is effective?" the answers of this question. 
To the question "which of these describe your practice to ensure the fasting of the patient prior to surgery?"; $72(62.1 \%)$ physicians answered that they stopped solid food intake 6 hours prior to surgery and the intake of fluids 2 hours prior to surgery. The responses given by the anesthetists and surgeons to this question have been presented in Figure 5. To the question "do you order carbohydrate loading for your patient or do you perform it in your patient?", 7 (6.0\%) physicians answered "yes," and 109 (94.0\%) physicians answered "no." All physicians answering the following question "if you have answered yes, can give information about what is your preferred method for performing the carbohydrate loading test?" reported that an $800 \mathrm{~mL}$ volume of carbohydrate-rich fluid was administered 8 hours prior to the surgery, and a $400 \mathrm{ml}$ volume was administered 2-3 hours prior to the surgery.

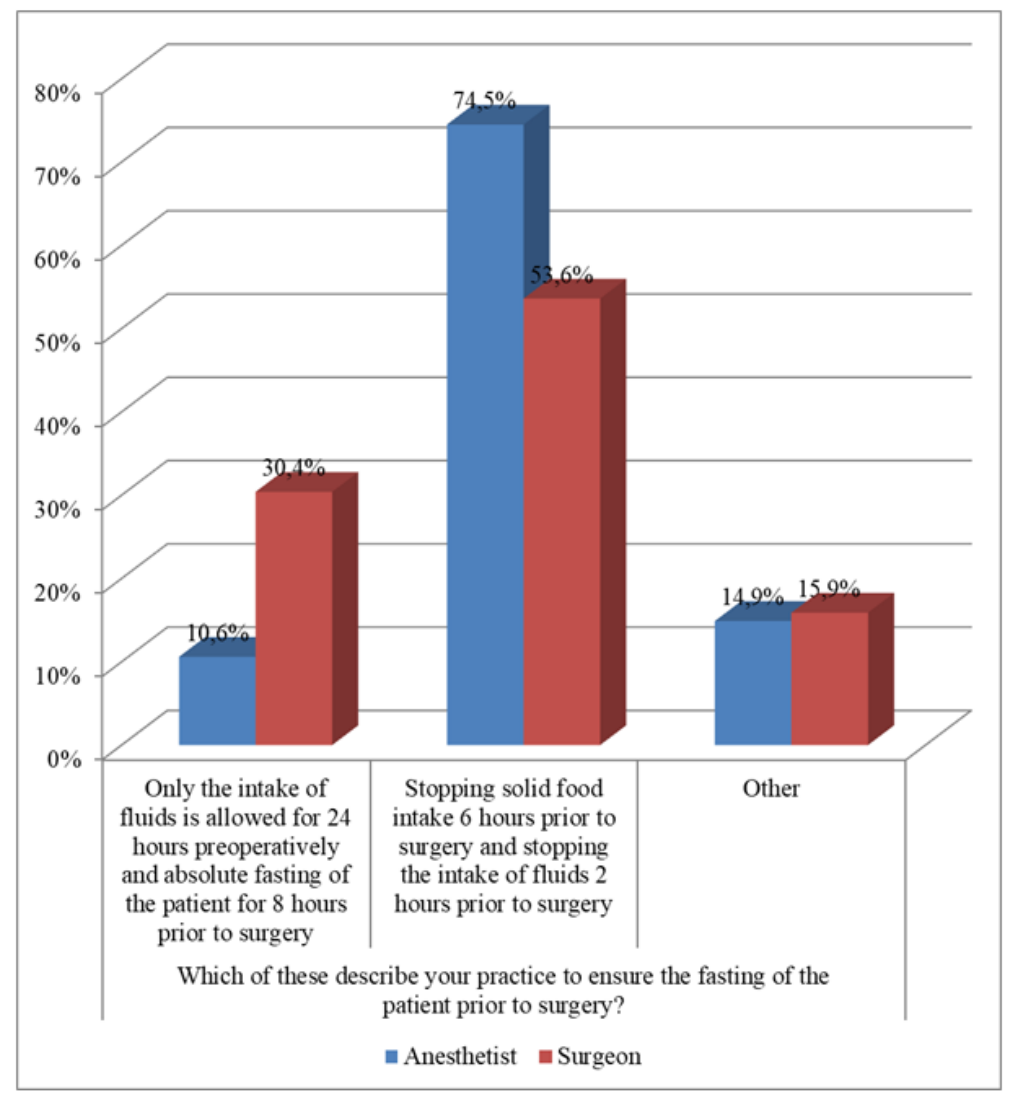

Figure 5: "Which of these describe your practice to ensure the fasting of the patient prior to surgery?" the answers of this question.

To the question "do you refer your patients, who are older or who will undergo major surgery, to an exercise program in the preoperative period?" 23 $(19.8 \%)$ physicians answered "yes."

The question, "do you order/administer premedication to patients in the preoperative period?", received the answer "yes" from 108 $(93.9 \%)$ physicians. The responses to this question received from the participating anesthetists and surgeons have been presented in Figure 6. The question, "To patients having an indication of prophylaxis therapy for thromboembolism, do you order/administer low-molecular-weight heparin prophylaxis in the night prior to the operation?", received the answer "yes" from 95 (82.6\%) physicians, received the answer "sometimes" from $14(12.2 \%)$ physicians, and received the answer "no" from $6(5.2 \%)$ physicians. 


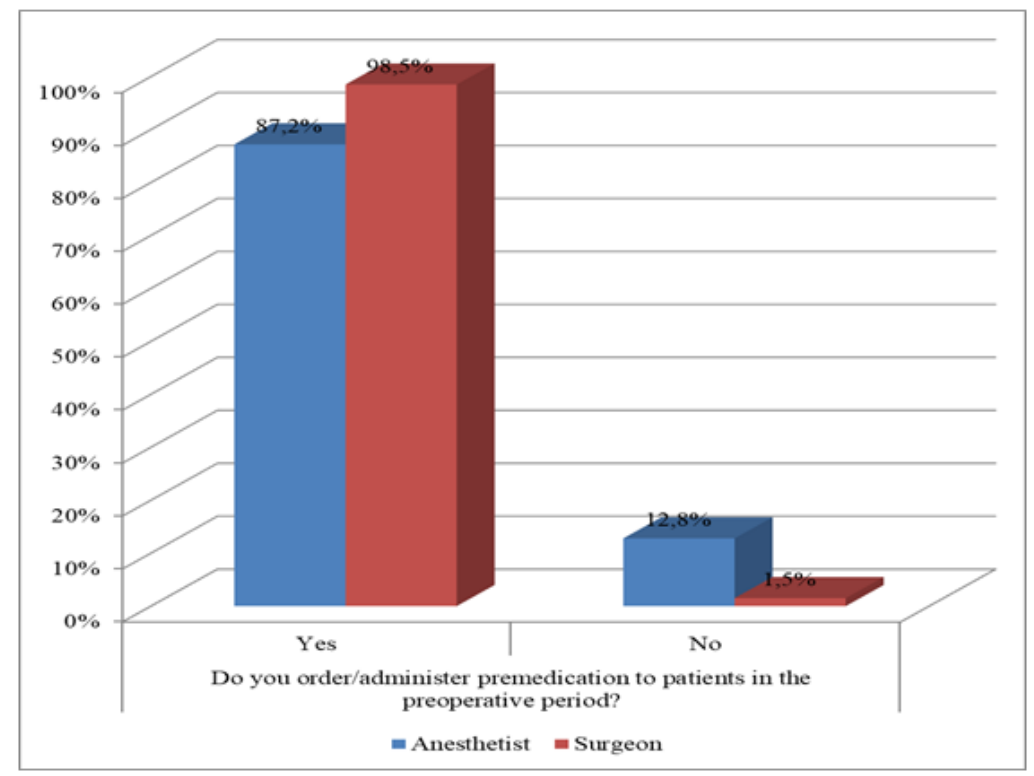

Figure 6: 'Do you order/administer premedication to patients in the preoperative period?', the answers of this question.

To the question, "do you monitor the blood glucose levels of diabetic patients in the preoperative period?", 115 (99.1\%) physicians answered "yes," and $1(0.9 \%)$ physician answered "no."

The answers received for the question, "for patients, who will undergo a major surgery, what is the lower normal limit of hemoglobin you accept in your clinical practice to indicate that you start treatment for anemia and schedule the surgery accordingly?", were as follows: $6(5.2 \%)$ physicians accepted a hemoglobin level of $<12$ for females and of $<13$ for males; $81 \quad(69.8 \%)$ physicians accepted hemoglobin levels of $<10$ for both females and males, and 25 physicians $(21.6 \%)$ accepted a hemoglobin level of $<7$ and of $<8$ for females and males, respectively. The responses of the participating anesthetists and surgeons to this question have been presented in Figure 7.

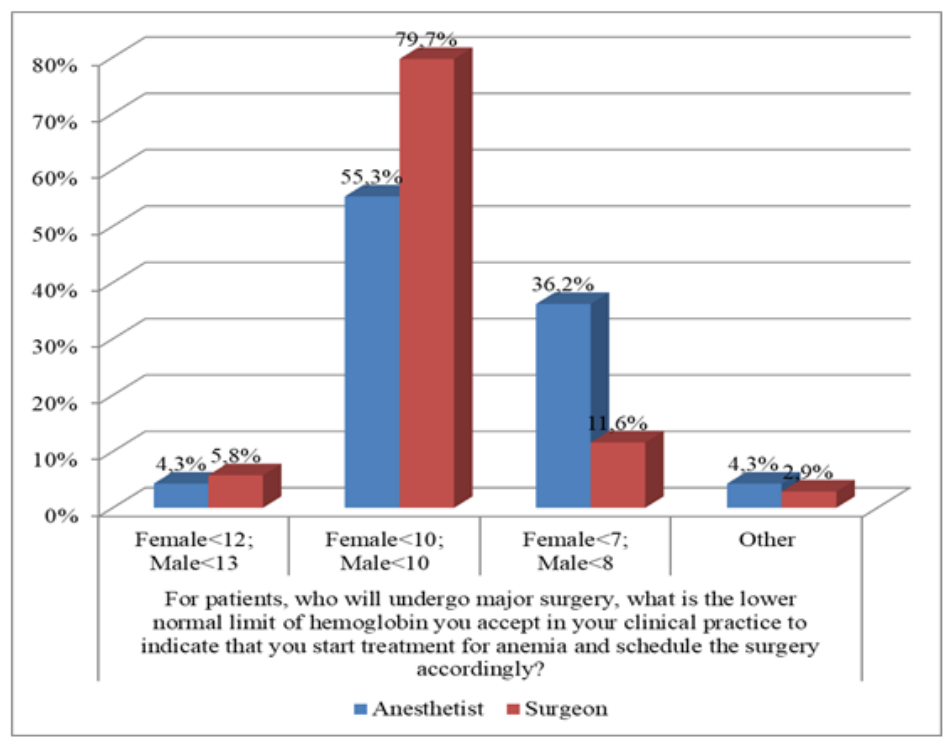

Figure 7. "'For patients, who will undergo major surgery, what is the lower normal limit of hemoglobin you accept in your clinical practice to indicate that you start treatment for anemia and schedule the surgery accordingly?" the answers of this question. 
The answers of the anesthetists and surgeons to the survey questions were grouped separately and, then, compared. Table 1 presents the responses, showing a statistically significant difference between the anesthetist group and the surgeon group.

Table 1: The survey questions and answers

\begin{tabular}{|c|c|c|c|c|}
\hline & & $\begin{array}{c}\text { Anestezist } \\
\text { n (\%) }\end{array}$ & $\begin{array}{c}\text { Cerrah } \\
\text { n (\%) }\end{array}$ & $\mathbf{p}$ \\
\hline \multirow{3}{*}{$\begin{array}{l}\text { What is your length of experience in your } \\
\text { area of specialty? }\end{array}$} & $0-5$ years & $16(\% 34,0)$ & $10(\% 14,5)$ & \multirow{3}{*}{0,044} \\
\hline & 6-9 years & $11(\% 23,4)$ & $23(\% 33,3)$ & \\
\hline & $>10$ years & $20(\% 42,6)$ & $36(\% 52,2)$ & \\
\hline \multirow{2}{*}{$\begin{array}{l}\text { In the preoperative period, do you stress to } \\
\text { your patients using alcohol that stopping } \\
\text { alcohol use is necessary for the period of } 4 \\
\text { weeks prior to surgery? }\end{array}$} & Yes & $28(\% 59,6)$ & $19(\% 27,5)$ & \multirow{2}{*}{0,001} \\
\hline & No & $19(\% 40,4)$ & $50(\% 72,5)$ & \\
\hline \multirow{4}{*}{$\begin{array}{l}\text { If you have answered yes, can give } \\
\text { information on whether it is effective? }\end{array}$} & $\begin{array}{l}\text { Yes, the patient undergoes surgery after } \\
\text { stopping alcohol use }\end{array}$ & $5(\% 16,7)$ & $9(\% 60,0)$ & \multirow{4}{*}{0,013} \\
\hline & $\begin{array}{l}\text { No, the patient does not like to delay } \\
\text { surgery }\end{array}$ & $15(\% 50,0)$ & $3(\% 20,0)$ & \\
\hline & $\begin{array}{l}\text { No, the surgeon does not like to delay } \\
\text { surgery even though the patient likes to } \\
\text { undergo surgery after stopping alcohol } \\
\text { use }\end{array}$ & $8(\% 26,7)$ & $1(\% 6,7)$ & \\
\hline & Other & $2(\% 6,7)$ & $2(\% 13,3)$ & \\
\hline \multirow{3}{*}{$\begin{array}{l}\text { Which of these describe your practice to } \\
\text { ensure the fasting of the patient prior to } \\
\text { surgery? }\end{array}$} & $\begin{array}{l}\text { Only the intake of fluids is allowed for } \\
24 \text { hours preoperatively and absolute } \\
\text { fasting of the patient for } 8 \text { hours prior to } \\
\text { surgery }\end{array}$ & $5(\% 10,6)$ & $21(\% 30,4)$ & \multirow{3}{*}{$\mathbf{0 , 0 3 2}$} \\
\hline & $\begin{array}{l}\text { Stopping solid food intake } 6 \text { hours prior } \\
\text { to surgery and stopping the intake of } \\
\text { fluids } 2 \text { hours prior to surgery }\end{array}$ & $35(\% 74,5)$ & $37(\% 53,6)$ & \\
\hline & Other & $7(\% 14,9)$ & $11(\% 15,9)$ & \\
\hline \multirow{2}{*}{$\begin{array}{l}\text { Do you order/administer premedication to } \\
\text { patients in the preoperative period? }\end{array}$} & Yes & $41(\% 87,2)$ & $67(\% 98,5)$ & \multirow{2}{*}{0,018} \\
\hline & No & $6(\% 12,8)$ & $1(\% 1,5)$ & \\
\hline \multirow{4}{*}{$\begin{array}{l}\text { For patients, who will undergo major } \\
\text { surgery, what is the lower normal limit of } \\
\text { hemoglobin you accept in your clinical } \\
\text { practice to indicate that you start treatment } \\
\text { for anemia and schedule the surgery } \\
\text { accordingly? }\end{array}$} & Female $<12 ;$ Male $<13$ & $2(\% 4,3)$ & $4(\% 5,8)$ & \multirow{4}{*}{0,015} \\
\hline & Female $<10 ;$ Male $<10$ & $26(\% 55,3)$ & $55(\% 79,7)$ & \\
\hline & Female $<7$; Male $<8$ & $17(\% 36,2)$ & $8(\% 11,6)$ & \\
\hline & Other & $2(\% 4,3)$ & $2(\% 2,9)$ & \\
\hline
\end{tabular}




\section{DISCUSSION}

ERAS aims to maintain the physiological functions of the individual and to ensure early mobilization in the postoperative period by reducing the intensity of the physical and psychological stress associated with the respective surgery ${ }^{1,3}$. A general preoperative evaluation is required for all patients, who will undergo elective surgery, in order to determine if the scheduled intervention will be appropriate for the particular patient ${ }^{3}$.

Aasa et al. ${ }^{4}$ conducted a study in 2013 and concluded that the item specifying the "information, training, and consultation to be provided to the patient" in the enhanced care protocols should be designed specifically for each individual patient and that every patient should be followed up during the whole process of care. All of the participating physicians in our study reported that they provided the necessary information to all of their patients.

The pulmonary effects of smoking can recover if individuals stop smoking 4 weeks prior to surgery. Interventions to stop smoking are associated with short-term smoking cessation periods, and the evidence about their potential in reducing the postoperative morbidity is poor ${ }^{5-8}$. In our study, the likelihood of patients achieving a positive outcome in stopping smoking was low, although $75.9 \%$ of the physicians stressed the requirement that smoking should be stopped 4 weeks prior to the operation.

The chronic effects of alcohol on the liver, the pancreas, and the central nervous system have been proven. The effects of perioperative alcohol intake on the cardiac functions, the coagulation system, the immune system, and the response to surgical stress affect the morbidity rates and increase the mortality rates by two or three folds. Stopping alcohol intake at least 4 weeks prior to surgery reduces the risk of postoperative complications; however, it does not significantly affect the mortality or the length of hospital stay ${ }^{8-11}$. Our study demonstrated that $40.5 \%$ of the participating physicians, comprising anesthetists mostly, stressed the importance of stopping alcohol intake 4 weeks prior to surgery to their patients but the likelihood of the patients achieving positive outcomes was low, similar to that of smoking cessation.

The study conducted by Faraoni et al. 12 demonstrated increased hospital mortality rates in anemic children. Perioperative anemia is associated with morbidity and mortality. Existing anemia should be diagnosed prior to elective surgery, and iron deficiency should be treated along with any underlying disorders. Treatment of preoperative anemia is critical to avoid transfusion and/or the adverse consequences of anemia ${ }^{1}$. This type of approach to treating preoperative anemia is considered both beneficial in improving patientassociated clinical outcomes and effective as a strategy for the efficacious use of healthcare resources along with reducing the costs ${ }^{13,14}$. In the general population, anemia is defined as having a hemoglobin level of $<120 \mathrm{~g} \mathrm{~L}^{-1}$ in females and of $<130 \mathrm{~g} \mathrm{~L}^{-1}$ in males ${ }^{15}$. Only $5.2 \%$ of all participating physicians in our study defined the lower normal limit of hemoglobin for starting anemia treatment in major surgery patients as a concentration of $<12$ for females and of $<13$ for males. It is clear that frequent review of guidelines is essential by practicing physicians.

There are studies in the literature proving that longterm stopping of oral intake of solid food and liquids cause postoperative insulin resistance and some metabolic inadequacies. Currently, oral intake of solid food and clear liquids are allowed until the 6-hour period and 2-hour period, respectively, prior to surgery. Preoperative carbohydrate loading has been demonstrated to reduce the hunger and thirst sensation, and the intensity of anxiety in the postoperative period ${ }^{16}$, ${ }^{17}$. In our study, $62.1 \%$ of the participating physicians reported that they stopped the oral intake of solid food and liquids in the $6^{\text {th }}$ and $2^{\text {nd }}$ hours respectively prior to surgery; however, only $6 \%$ reported that they performed carbohydrate loading. We think that regular training within the institutions will be useful for the physicians.

Preoperative physical treatment or rehabilitation (prehabilitation) affects postoperative functions and recovery positively. Although it is observed to reduce the incidence of postoperative complications, there is still a need for further studies ${ }^{18}$. Our study revealed that $19.8 \%$ of the participating physicians referred their patients to exercise programs in the preoperative period. This low rate is observed to be associated with the lack of adequate preoperative time for both the physician and the patient, inadequate circumstances for feasibility, and inadequate level of information of the physicians about the subject.

The incidences of asymptomatic deep vein thrombosis and fatal pulmonary embolism are $30 \%$ and $1 \%$, respectively, in the surgery patients, who did not receive prophylactic treatment of thromboembolism. The patient group, having an indication for receiving antithrombotic prophylaxis, has been investigated in numerous 
studies and has been defined clearly. The risk of thromboembolism increases in patients with malignant diseases, in patients undergoing pelvic surgery, in hypercoagulable conditions, and in patients receiving corticosteroids in the preoperative period. ERAS protocol does not introduce a new approach to the conventional clinical practice performed for these clinical conditions but recommends treatment at appropriate doses for the patients having an indication 19,20 . In our study, $82.6 \%$ of the participating physicians reported that they started prophylactic treatment for the risk of thromboembolism.

Diabetes mellitus is a common disease affecting people of all ages and increasing the rates of morbidity and mortality. Diabetic patients require more frequent perioperative and preoperative care compared to non-diabetic patients. Physicians should closely follow up this patient group in order to ensure optimum perioperative management and start treatment if required ${ }^{21}$. In our study; excluding only one physician, all participating physicians reported that they followed up blood glucose levels of their diabetic patients in the preoperative period. Of the participating physicians in our study, $93.9 \%$ reported that they administered premedication preoperatively. We suggest that short-acting agents should be preferred for premedication for the purpose of preventing anxiety ${ }^{22}$.

In conclusion; our survey study conducted with the participation of physicians with an experience of more than 10 years demonstrated favorable outcomes, revealing that all physicians provided information and training for their patients in the preoperative period and all but 1 physician followed up the blood sugar level of diabetic patients for regulating the blood sugar levels. However; we are of the opinion that further collaboration of physicians within a team concept and in compliance with the preoperative optimization guidelines will be useful to ensure early and fast recovery in the postoperative period by limiting the tobacco/alcohol use of patients in the preoperative period, providing appropriate nutrition preoperatively, enabling access of patients to rehabilitation, administering adequate premedication, and providing anemia management.

\section{REFERENCES}

1. Dağıstanlı S, Kalaycı MU, Kara Y. Genel Cerrahide ERAS Protokolünün Değerlendirilmesi. IKKSST Derg 2018;10(Ek say1):9-20.
2. Martin D, Roulin D, Grass F, et al. A multicentre qualitative study was assessing implementation of an Enhanced Recovery After Surgery program. Clin Nutr. 2018 Dec;37:2172-2177.

3. D'Andrilli A, Rendina EA. Enhanced recovery after surgery (ERAS) and fast-track in video-assisted thoracic surgery (VATS) lobectomy: preoperative optimization and care-plans. J Vis Surg. 2018 Jan 5;4:4.

4. Aasa A, Hovbäck M, Berterö CM. The importance of preoperative information for patient participation in colorectal surgery care. J Clin Nurs. 2013 Jun;22(11-12):1604-12.

5. Lindstrom D, Sadr Azodi O, Wladis A, Tonnesen H, Linder S, Nasell H, et al. Effects of a perioperative smoking cessation intervention on postoperative complications: a randomized trial. Ann Surg. 2008;248(5):73945.

6. Thomsen $\mathrm{T}$, Villebro $\mathrm{N}$, Moller AM. Interventions for preoperative smoking cessation. Cochrane Database Syst Rev. 2010;7(7):CD002294.

7. Sorensen LT, Karlsmark T, Gottrup F. Abstinence from smoking reduces incisional wound infection: a randomized controlled trial. Ann Surg. 2003 Jul;238(1):1-5.

8. Tuna PT, Kurşun Ş. Kolorektal Cerrahisinde Hızlandırılmış Bakım Protokolleri ve Hemşirelik Bakımı. DEUHFED 2018, 11 (2), 180-8.

9. Tonnesen H, Kehlet $\mathrm{H}$. Preoperative alcoholism and postoperative morbidity. $\mathrm{Br} \mathrm{J}$ Surg. 1999;86(7):869-74.

10. Tonnesen H, Rosenberg J, Nielsen HJ, Rasmussen V, Hauge C, Pedersen IK, et al. Effect of preoperative abstinence on poor postoperative outcome in alcohol misusers: randomized controlled trial. BMJ. 1999;318(7194):1311-6.

11. Gustafsson, U. O., Scott, M. J., Schwenk, W., Demartines, N., Roulin, D., Francis, N., et al. (2013). Guidelines for perioperative care in elective colonic surgery: Enhanced recovery after surgery (ERAS) society recommendations. World Journal of Surgery, 37, 259-284.

12. Faraoni D, DiNardo JA, Goobie SM. Relationship Between Preoperative Anemia and In-Hospital Mortality in Children Undergoing Noncardiac Surgery. Anesth Analg. 2016 Dec;123(6):1582-1587.

13. Muñoz M, Gómez-Ramírez S, KozekLangeneker S, Shander A, Richards T, Pavía J. 'Fit to fly': overcoming barriers to preoperative hemoglobin optimization in 
surgical patients. $\mathrm{Br} \quad \mathrm{J}$ Anaesth. 2015 Jul;115(1):15-24.

14. Fowler AJ, Ahmad T, Phull MK, Allard S, Gillies MA, Pearse RM. A meta-analysis of the association between preoperative anemia and mortality after surgery. Br J Surg. 2015 Oct;102(11):1314-24.

15. World Health Organization. Nutritional anemias.

1968. https://apps.who.int/iris/bitstream/handle/106 65/40707/WHO_TRS_405.pdf? sequence $=1$ (accessed 27/06/2019).

16. Gustafsson UO, Nygren J, Thorell A, Soop $\mathrm{M}$, Hellstrom PM, Ljungqvist $\mathrm{O}$, et al. Preoperative carbohydrate loading may be used in type 2 diabetes patients. Acta Anaesthesiol Scand. 2008;52:946e51.

17. Breuer JP, von DV, von Heymann C, Griesbach M, von Schickfus M, Mackh E, et al. Preoperative oral carbohydrate administration to ASA III-IV patients undergoing elective cardiac surgery. Anesth Analg. 2006;103:1099e108.
18. Moran J, Guinan E, McCormick P, Larkin J, Mockler D, Hussey J, et al. The ability of prehabilitation to influence postoperative outcome after intra-abdominal operation: A systematic review and meta-analysis. Surgery. 2016 Nov;160(5):1189-1201.

19. Fleming FJ, Kim MJ, Salloum RM, Young $\mathrm{KC}$, Monson JR. How much do we need to worry about venous thromboembolism after hospital discharge? A study of colorectal surgery patients using the National Surgical Quality Improvement Program database. Dis Colon Rectum 2010 Oct;53(10):1355-60.

20. Ersoy E, Gündoğdu H. Cerrahi sonras1 iyileşmenin hızlandırılması. Turk J Surg. 2007;23(1):035-40.

21. Kadoi Y. Anesthetic considerations in diabetic patients. Part I: preoperative considerations of patients with diabetes mellitus. J Anesth. 2010 Oct;24(5):739-47.

22. Ip HY, Abrishami A, Peng PW, Wong J, Chung F. Predictors of postoperative pain and analgesic consumption: a qualitative systematic review. Anesthesiology. 2009 Sep;111(3):657-77. 